\title{
Multiple methods increase detection of large and medium-sized mammals: working with volunteers in south-eastern Oman
}

\author{
Marcelo Mazzolli, Taiana Haag, Beatriz G. Lippert, Eduardo Eizirik \\ Matthias L.A. Hammer and Khalid Al Hikmani
}

\begin{abstract}
We compared the effectiveness of various methods for surveying medium and large wild mammals in southern Oman. Working with volunteers recruited by Biosphere Expeditions, wildlife professionals and local rangers, we used direct observation, camera traps, sign surveys (tracks and/or dung) and molecular scatology to study 66 sampling units of $2 \times 2 \mathrm{~km}$ (grid cells) in an area of $32 \times 36 \mathrm{~km}$ during a 4-week period in February-March 2011. Sixteen mammal species were recorded, and the largest numbers of species were recorded by sign surveys and camera traps (both $n=9$ ); sign surveys, direct sightings and DNA scatology recorded species across the largest number of grid cells. For species with a sample size large enough for comparison (i.e. detected in $\geq 8$ grid cells), DNA scatology proved most effective for detecting caracal Caracal caracal, signs for hyaena Hyaena hyaena, ibex Capra nubiana, porcupine Hystrix indica and hyrax Procavia capensis, and signs and direct sightings for mountain gazelle Gazella gazella. Clustering, in which records from multiple methods are either adjacent or overlapping, was highest $(\geq 76 \%)$ for the wolf Canis lupus, porcupine, ibex and gazelle. Our results indicate the best methods to detect and record the distributions of individual species in the study area, and demonstrate the advantage of using multiple methods to reduce the risk of false absences or partial detections. Our findings also highlight the potential of clustering as a means of cross-checking results of observations that are skill-dependent, which is particularly useful when employing a large workforce.
\end{abstract}

Keywords Citizen science, Dhofar, mammals, methods, Middle East, Oman, sampling, volunteer

Marcelo Mazzolli (Corresponding author) Projeto Puma, Av. Castelo Branco 170, CP 525, 88509-900, Lages, Santa Catarina, Brazil

E-mail marcelo@projeto-puma.org

Taiana HaAg, Beatriz G. Lippert and Eduardo Eizirik, Laboratory of Genomic and Molecular Biology of the Pontifícia Universidade Católica of Rio Grande do Sul, Brazil

Matthias L.A. Hammer Biosphere Expeditions, UK

Khalid Al Hikmani Office for Conservation of the Environment, Diwan of Royal Court, Oman

Received 23 May 2014. Revision requested 26 June 2014.

Accepted 29 July 2015. First published online 6 May 2016.

\section{Introduction}

T nowing which methods are most efficient for record-ing target species is fundamental to the success of short-duration research expeditions and surveys. Without such prior knowledge, efforts and resources may be wasted by using methods that are not appropriate for recording the species of interest. More broadly, failure to record species that are present may result in misleading descriptions of distribution and abundance. These potential biases have not been adequately addressed in the scientific literature, and most of the statistics used to infer density and presence of species have been developed using a single field method (e.g. Otis et al., 1978; Burnham et al., 1980; Boulinier et al., 1998; Karanth \& Nichols, 1998; MacKenzie et al., 2002; MacKenzie \& Nichols, 2004). More recently, models have been developed that incorporate data from multiple methods (e.g. Nichols et al., 2008), an acknowledgement that single-method approaches may not be ideal in all research situations, although not everyone agrees (Otto \& Roloff, 2011).

Earlier use of multiple survey methods (e.g. Zielinski \& Kucera, 1995) is now becoming more popular (Silveira et al., 2003; Gompper et al., 2006; Nichols et al., 2008; Nomani et al., 2008; Ausband et al., 2014). Previously, particular methods were advocated for estimating the abundance and occupancy of particular species or taxonomic groups (e.g. Karanth et al., 2004; Balme et al., 2009; Mondol et al., 2009). However, sampling rare species (or populations) using a single method, such as camera trapping, necessitates increasing survey effort, often to a level that may be logistically unrealistic (Shannon et al., 2014). Furthermore, there is increasing evidence that different methods yield different detection probabilities (e.g. Nichols et al., 2008; Otto \& Roloff, 2011) and may produce different estimates of abundance or presence (e.g. Gompper et al., 2006; Nomani et al., 2008; Otto \& Roloff, 2011). It is therefore possible that two methods may result in two different estimates, even when detection probability statistics are used, highlighting the relevance of analysing the efficiency of multiple methods.

Here we demonstrate how the efficiency of sampling methods varies by species, and that single sampling methods cannot be prescribed in a generalized way for all study situations. We also consider the potential for bias when 


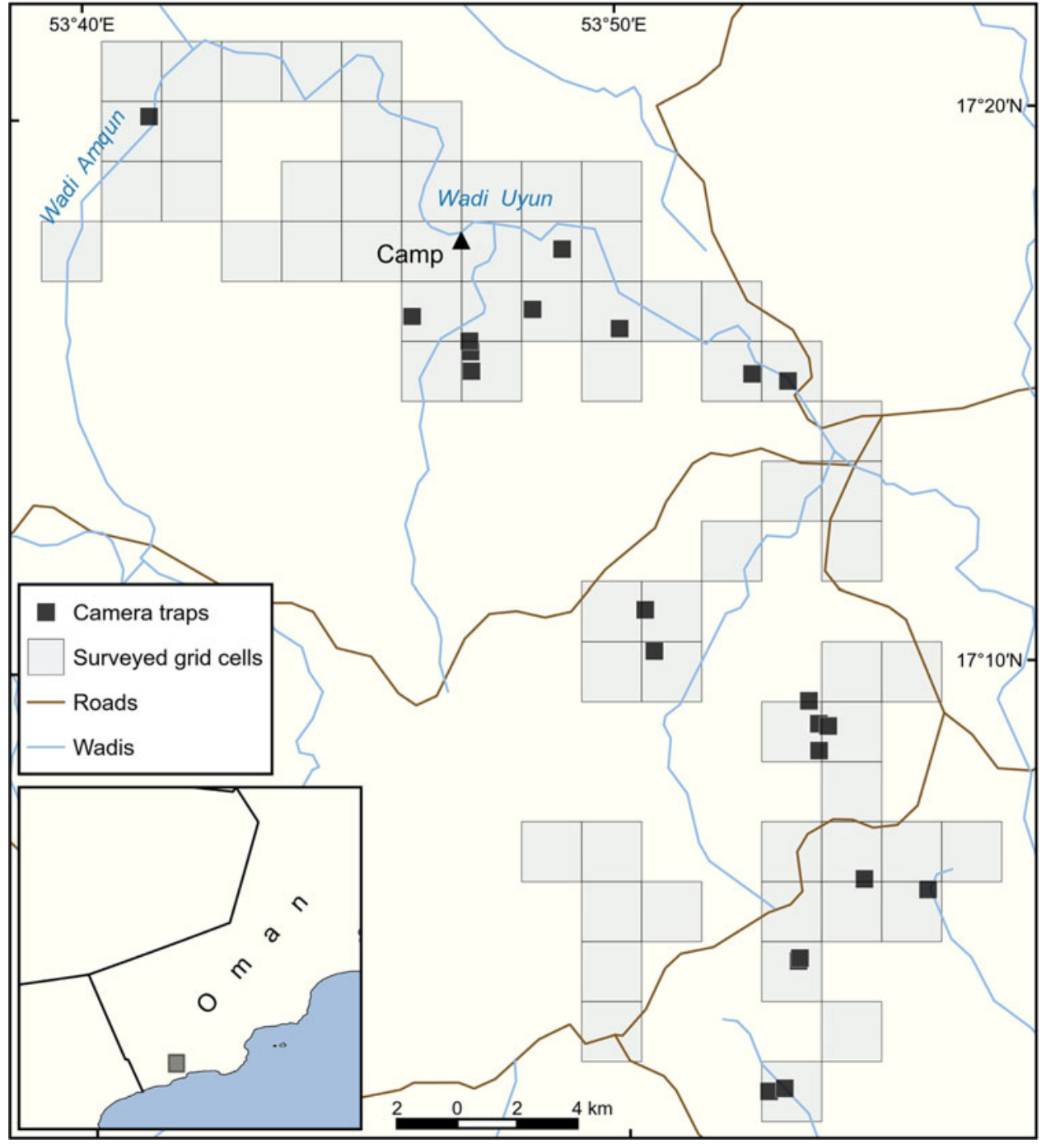

FIG. 1 The $662 \times 2 \mathrm{~km}$ cells surveyed, by various methods (Table 1), for large and medium-sized mammals in south-eastern Oman, with the locations of camera trap stations. there is a large team working in the field, a matter that may be of particular concern when volunteers are involved. When multiple sampling methods are used, particularly those that are less dependent on observer skill, the results may be cross-checked, and we examined how clustering of grid cells from multiple methods may be used to do this for individual species.

\section{Study area}

The $32 \times 36 \mathrm{~km}$ study area in the south-west Dhofar Mountains (part of the Nejd or Jabal Al Qara region) in Oman, in the south-east Arabian Peninsula, was delimited by Wadi Uyun in the north and the cliffs above the Salalah plains in the south. The topography varies from wadis (seasonally dry riverbeds) to mountain ridges and escarpments. Vegetation coverage increases towards the southern monsoon-fed regions but consists of scattered bushes and does not hinder visibility.

\section{Methods}

Two groups, of 13 and 21 participants, carried out surveys during 6-18 February and 20 February-4 March 2011, respectively. Each group comprised wildlife professionals, local rangers, and volunteers recruited by Biosphere Expeditions, who received training in data collection. An expedition leader (Paul O'Dowd), the expedition scientist (MM) and the national scientist $(\mathrm{KH})$ were present throughout the expedition. Each group was divided into 3-4 subgroups to maximize the area surveyed.

\section{Sampling and analysis of signs}

We surveyed $662 \times 2 \mathrm{~km}$ sampling units (grid cells; Fig. 1) for medium and large mammals during a 25 -day period. The size of the area was determined by the capacity of the survey team to cover the area from the base camp, and the cell size was determined by the need to cover areas large enough to 
TABLE 1 Large and medium-sized mammal species recorded in south-eastern Oman (Fig. 1), with their global and regional Red List status, the number of cells in which they were recorded (and the total number of records) by five methods (sightings, signs, camera traps, bones and carcasses, and faecal DNA analysis) and, for the seven most commonly recorded species (i.e. recorded in $>8$ cells), the number of cells in which two or more methods recorded presence in two or more adjoining cells (i.e. cells that were clustered, with the percentage of the total number of cells in parentheses). Signs are mostly tracks and faecal samples (dung) identified by eye.

\begin{tabular}{|c|c|c|c|c|c|c|c|c|c|}
\hline \multirow[b]{2}{*}{ Species } & \multirow[b]{2}{*}{$\begin{array}{l}\text { Global } \\
\text { status }^{1}\end{array}$} & \multirow[b]{2}{*}{$\begin{array}{l}\text { Regional } \\
\text { status }^{2}\end{array}$} & \multicolumn{6}{|c|}{ No. of cells in which species recorded (no. of records) ${ }^{3}$} & \multirow{2}{*}{$\begin{array}{l}\text { Cell clustering } \\
\text { (\% of total } \\
\text { cells) }\end{array}$} \\
\hline & & & Sighting & Sign & $\begin{array}{l}\text { Camera } \\
\text { trap }\end{array}$ & $\begin{array}{l}\text { Bones \& } \\
\text { carcasses }\end{array}$ & $\begin{array}{l}\text { DNA } \\
\text { analysis }\end{array}$ & Total & \\
\hline \multicolumn{10}{|l|}{ Carnivora } \\
\hline $\begin{array}{l}\text { Leopard Panthera } \\
\text { pardus nimr }\end{array}$ & $\mathrm{CR}$ & CR & & & & & $1(1)$ & & \\
\hline $\begin{array}{l}\text { Caracal Caracal } \\
\text { caracal }\end{array}$ & $\mathrm{LC}$ & $\mathrm{LC}$ & & $1($ track, $\mathrm{n}=1)$ & $2(2)$ & & $9(10)$ & 11 & $5(45)$ \\
\hline $\begin{array}{l}\text { Gordon's wildcat Felis } \\
\text { silvestris }\end{array}$ & $\mathrm{LC}$ & NT & & & & & $1(1)$ & & \\
\hline $\begin{array}{l}\text { Striped hyaena } \\
\text { Hyaena hyaena }\end{array}$ & NT & $\mathrm{EN}$ & & 26 (tracks, $\mathrm{n}=40$ ) & $3(20)$ & & $1(1)$ & 26 & $10(38)$ \\
\hline Grey wolf Canis lupus & LC & $\mathrm{EN}$ & & $7($ tracks, $n=9)$ & $2(2)$ & $1(1)$ & $4(10)$ & 8 & $5(63)$ \\
\hline Red fox Vulpes vulpes & LC & LC & & $1(1)$ & & $1(1)$ & & & \\
\hline $\begin{array}{l}\text { Blanford's fox Vulpes } \\
\text { cana }\end{array}$ & $\mathrm{LC}$ & VU & & & $2(2)$ & & & & \\
\hline $\begin{array}{l}\text { Honey badger } \\
\text { Mellivora capensis }\end{array}$ & $\mathrm{LC}$ & NT & & & $1(3)$ & & & & \\
\hline $\begin{array}{l}\text { Small spotted genet } \\
\text { Genetta genetta }\end{array}$ & $\mathrm{LC}$ & $\mathrm{LC}$ & & & $1(4)$ & & & & \\
\hline $\begin{array}{l}\text { White-tailed mon- } \\
\text { goose Ichneumia } \\
\text { albicauda }\end{array}$ & $\mathrm{LC}$ & $\mathrm{LC}$ & & & $1(1)$ & & & & \\
\hline Artiodactyla & & & & & & & & & \\
\hline $\begin{array}{l}\text { Mountain gazelle } \\
\text { Gazella gazella }\end{array}$ & VU & & $18(31)$ & $\begin{array}{l}41 \text { (tracks, } \mathrm{n}=47 \\
\text { dung, } \mathrm{n}=48)\end{array}$ & & $1(1)$ & & 46 & $41(89)$ \\
\hline $\begin{array}{l}\text { Nubian ibex Capra } \\
\text { nubiana }\end{array}$ & VU & & $1(1)$ & $\begin{array}{l}23 \text { (tracks, } \mathrm{n}=17 \\
\text { dung, } \mathrm{n}=34 \text { ) }\end{array}$ & $1(1)$ & $1(1)$ & & 24 & $21(88)$ \\
\hline Hyracoidea & & & & & & & & & \\
\hline $\begin{array}{l}\text { Rock hyrax Procavia } \\
\text { capensis }\end{array}$ & $\mathrm{LC}$ & & $1(2)$ & $\begin{array}{l}28 \text { (tracks, } \mathrm{n}=10 \\
\text { dung, } \mathrm{n}=40 \text { ) }\end{array}$ & $1(17)$ & $2(2)$ & & 28 & $11(39)$ \\
\hline Lagomorpha & & & & & & & & & \\
\hline $\begin{array}{l}\text { Cape hare Lepus } \\
\text { capensis }\end{array}$ & $\mathrm{LC}$ & & & $\begin{array}{l}2(\text { track, } \mathrm{n}=1 \\
\text { dung, } \mathrm{n}=2)\end{array}$ & & & & & \\
\hline Rodentia & & & & & & & & & \\
\hline $\begin{array}{l}\text { Indian crested porcu- } \\
\text { pine Hystrix indica }\end{array}$ & $\mathrm{LC}$ & & & $\begin{array}{l}31 \text { (tracks, } \mathrm{n}=26 \\
\text { dung, } \mathrm{n}=47 \\
\text { quills, } \mathrm{n}=9 \text { ) }\end{array}$ & $5(35)$ & & & 38 & $29(76)$ \\
\hline $\begin{array}{l}\text { Hedgehog } \\
\text { Paraechinus aethiopi- } \\
\text { cus or P. hypomelas }\end{array}$ & $\mathrm{LC}$ & & $2(2)$ & & & & & & \\
\hline
\end{tabular}

${ }^{1}$ CR, Critically Endangered; EN, Endangered; VU, Vulnerable; NT, Near Threatened; LC, Least Concern; IUCN (2015).

${ }^{2}$ Mallon \& Budd (2011).

${ }^{3}$ Blank cells indicate the species was not recorded by that method.

be relevant for describing the distributions of large and medium mammals.

Identification methods included recording mammalian signs (mainly tracks and herbivore dung), DNA analysis of carnivore scats, visual recording, and camera traps. Carnivore scats were not identified macroscopically because of the likelihood of significant error (Davison et al.,
2002; Harrison, 2002; Perez et al., 2006; Janecka et al., 2008; Vanstreels et al., 2010; Kelly et al., 2012; Mazzolli \& Hammer, 2013), and therefore samples were collected for DNA-based species identification.

The presence or absence and frequency of target species was recorded using the general location given by a grid consisting of $2 \times 2 \mathrm{~km}$ cells, the code of which was displayed in 
the global positioning system (GPS) of each surveyor. Once a species or signs of it were found in a given cell, it was scored as containing the species. Species were recorded only once for each cell during a given survey (i.e. there was no double counting). Signs not identified directly in the field were collected (in the case of scats) or photographed with a scale (in the case of tracks). Twenty passive infrared camera traps (Cuddeback, Green Bay, USA) were deployed pseudo-randomly in 15 cells, at locations such as waterholes and known animal trails, aiming for the widest coverage possible. Camera traps were active day and night, and set at $40 \mathrm{~cm}$ above ground, with the beam directed slightly downwards.

\section{Training}

Training of the survey group included an introduction to conservation issues, followed by training on practical aspects of the survey, such as species identification from tracks and dung, and the use of GPS and data recording sheets, which lasted 2 days. Before volunteers were allowed to carry out surveys on their own, experienced personnel accompanied them for at least 2 additional days during field surveys, to provide further teaching and to check their knowledge. To reduce identification error, group members were instructed to bring herbivore dung to base camp if they were unable to identify the species in the field. They were also briefed on how to photograph tracks (using a scale) for later identification.

\section{DNA analysis of faecal samples}

We used DNA analysis of scats to identify species of carnivores. Extractions were performed using the QIAamp DNA Stool Mini Kit (QIAGEN, Hilden, Germany), following the manufacturer's instructions. The extractions were carried out in a UV-sterilized laminar flow hood dedicated to the analysis of DNA from non-invasive samples. Each batch of 10 extractions included one negative extraction control to monitor the occurrence of contamination with extrinsic DNA.

To identify species from each scat we used an assay that targets a short segment of the mtDNA ATP synthase subunit 6 (ATP6) gene, using the reverse primer ATP6-DR1 and the forward primer ATP6-DF3. We used polymerase chain reactions (PCR) for the ATP6 gene, following the protocols described by Haag et al. (2009, 2010).

The PCR products were visualized on a $1 \%$ agarose gel stained with GelRed (Biotium, Hayward, USA), purified with PEG 80oo, sequenced using the DYEnamic ET Dye Terminator Sequencing Kit (GE Healthcare, Hatfield, UK) and analysed in a MegaBACE 1000 automated sequencer (GE Healthcare). Sequence chromatograms were edited and analysed using FinchTV v. 1.4.o (Geospiza, Inc.,
Seattle, USA). The ATP6 gene fragment obtained from each faecal sample was compared with reference sequence.

\section{Geographical information system (GIS) and mapping}

The mapping procedures and analysis were designed to be easily integrated and replicated across multiple expeditions by personnel with no formal training in GIS (Mazzolli \& Hammer, 2013). The main reference map used was at $1: 100,000$ scale (Uyūn, NE 39-12F; National Survey Authority, Sultanate of Oman), prepared using aerial photographs from 1993 and field updates from 1999, with grid data in the Universal Transverse Mercator projection (zones 39 and 40, WGS 84 datum).

An image of the study area was imported and georeferenced in TrackMaker (Geo Studio Technology, Minas Gerais, Brazil). A grid of $2 \times 2 \mathrm{~km}$ cells covering the area was uploaded into GPS units, to aid navigation and data collection. As the work progressed, additional features such as access roads, base camp, trails and camera-trap locations were added to the GPS units, and were later overlaid onto a topographic map in TrackMaker, which was then edited and redrawn in Adobe Photoshop (Adobe Systems Inc., San Jose, USA) to leave only the features of interest.

\section{Cluster analysis}

Maps were produced for each target species, with cells displaying their recorded distribution and the methods by which they were recorded. The number of overlapping or adjacent cells in which two or more methods recorded the presence of a given species was counted. If such clustered cells occurred in $>70 \%$ of the total number of cells in which a species was recorded, we considered that two or more methods corroborated each other.

We analysed clustered features without using automated GIS methods because the latter depend on data points or other features that represent an 'excess of events' in geographical space (Jacquez, 2008). Our data were not clustered in this sense. This was done to avoid autocorrelation, to approximate the format of data collected to that of the processed data (data were processed as clusters of cells, not as data points), and to cover as much area as possible by avoiding spending time on redundant recording of species in a single cell. Furthermore, there are concerns regarding the accuracy of automated GIS clustering (Hamfelt et al., 2011; Murray et al., 2012).

\section{Results}

We recorded 16 species of medium and large mammals (Table 1). The efficiency of the identification methods varied for each species. Seven species were recorded exclusively by a single method. Leopard Panthera pardus nimr and wildcat 
Felis silvestris gordoni were recorded in single cells exclusively by DNA analysis. DNA analysis was also more efficient than other methods in detecting caracal Caracal caracal, and contributed substantially to detecting wolves Canis lupus. Wolf and hyaena Hyaena hyaena were recorded predominantly by tracks; gazelle Gazella gazella by tracks, dung and sightings; ibex Capra nubiana by tracks and dung; and porcupine Hystrix indica and hyrax Procavia capensis by dung (Table 1).

Camera traps also recorded species that were not recorded by other means, namely the honey badger Mellivora capensis, little spotted genet Genetta genetta, mongoose Ichneumia albicauda and Blanford's fox Vupes cana. Camera traps yielded high recording frequencies for the hyaena, hyrax and porcupine, but they were localized in only a few cells compared with results from other methods. The hedgehog Paraechinus sp. was the only taxon exclusively recorded by direct observation.

Clustering of cells in the grid space was highest for wolf, gazelle, ibex and porcupine; i.e. $\geq 76 \%$ of the distribution of these species were recorded by two or more methods in two or more adjoining cells. For the other species with a sufficiently large sample size $(n>8)$ for comparison (hyaena, caracal and hyrax), clustering was $<63 \%$ (Table 1 ).

\section{Discussion}

\section{Comparison of methods}

Our results show that the efficiency of detection methods varies by species, with one or two methods often outperforming others. For several species different methods produced different spatial distributions, suggesting a higher detection efficiency of multiple methods used in combination.

Previous studies have demonstrated differences in detection rates across methods, even at longer sampling intervals (e.g. Zielinski \& Kucera, 1995; Gompper et al., 2006; Vine et al., 2009). Although camera traps are one of the tools most recommended for recording and monitoring wildlife (e.g. Silveira et al., 2003; Balme et al., 2009), in our study they did not detect six species, including the Critically Endangered Arabian leopard, and recorded the hyaena in only three of the 26 cells where the species was recorded, and the ibex in only one of 24 cells where it was recorded. Even if camera-trap sampling for hyaena and ibex were equalized for the whole study area (simulating their deployment in all 66 surveyed grid cells) by multiplying the number of grid cells recorded (camera traps were deployed in 15 cells) by $4.4(15 \times 4.4=66$ cells $)$, and presuming the same recording rate, camera traps would have recorded ibex in six times fewer cells and hyaena in half of the number of cells in which they were recorded by other sampling methods.

Although gazelles were recorded in 46 cells using other methods, the species was not recorded by camera traps.
Thus there are cases in which meaningful parameter estimates cannot be obtained, regardless of one's statistical skills (Guillera-Arroita et al., 2014). Camera traps similarly returned a low sample size for ibex and leopards, and did not detect gazelles, in neighbouring Yemen (Khorozyan et al., 2014). Similarly, in Jabal Samhan recording rates for some species were found to vary greatly depending on the habitats sampled (Spalton et al., 2006); as other methods were not used we cannot know whether these findings are a true indication of the occurrence/absence of the species or a sampling artefact.

Our findings indicate that no single method should be relied on in all situations. The most appropriate method or combination of methods will depend on the target species, population and region, and on the parameters of interest. In a study in Slovakia, bears Ursus arctos were detected by tracks in 17 grid cells, but in only one cell by camera traps, and wolves and lynxes Lynx lynx were detected in up to 10 times more cells by tracks than by other methods (Hulik et al., 2015). We do not know how the detection probabilities of survey methods vary across the range of a single species, a variation that is probably associated with density. For leopards, for example, scrapes and tracks have been shown to be an efficient method to detect their presence in Jabal Samhan Nature Reserve in the east of Dhofar (Spalton, 2000), even during short surveys, whereas camera trapping is useful during longer surveys (Spalton et al., 2006; Spalton \& Al Hikmani, 2014). However, short surveys of our study site in south-west Dhofar did not yield a high frequency of records, suggesting that leopards are rare in the area (Mazzolli, 2009; this study), and this has since been confirmed (Al Hikmani et al., 2015). Similarly, jaguars in the Atlantic Rainforest of Brazil now occur at such low densities that they were not detected by camera traps during a 6-year study, and were detected by tracks in only four instances (Mazzolli et al., 2013); in contrast, both camera traps and track surveys repeatedly recorded jaguars during an 11-day survey in Madre de Dios, Peru (Lee et al., 2010). We do not contest the value of camera trapping as a survey method (it successfully detected species that were not detected by other methods in our study) but it may not always be reliable in detecting species throughout their range.

\section{Cross-checking results with cluster analysis}

The role of volunteers in research has been widely recognized and is increasing (Brightsmith et al., 2008). Volunteers are particularly essential in large-scale monitoring programmes (Howe et al., 1995; Newman et al., 2003; Sauer et al., 2003; Kindberg et al., 2009; Schmeller et al., 2009). Participation of volunteers requires protocols that are easy to follow, and the data collected has to be scrutinized carefully and discarded if suspect or unreliable (Cohn, 2008). 
Training is fundamental for securing unbiased data. In a deer monitoring study using pellet group counts volunteers received 5 hours of training using slides, yet they were only able to identify correctly $68 \%$ of deer droppings during the study (Buesching et al., 2014). However, in our study volunteers worked in groups, creating collaborative conditions that probably resulted in improved accuracy. Furthermore, they received 2 days of intensive training and had the opportunity to practise with scientists in the field for at least 2 more days before working on their own.

In such studies data quality also needs to be assessed, for which we used a post hoc evaluation with cluster analysis. The idea is that any inconsistencies will become apparent when using several methods for cross-validation. It would be reasonable to assume that contradictory findings from various methods could be an indication of observer error, but this is not always the case. The chance of surveyed cells clustering reduces when a single method notably outperforms others. In this case even if cells with records from different methods are overlapping or neighbouring, they will be a low proportion of all cells and therefore the measure of clustering will be low. This cluster analysis requires that at least two methods have records for a similar number of cells. A useful future improvement would be to incorporate an additional measure to corroborate the detection methods. We found a substantial spatial similarity of results among various methods for the wolf, gazelle, ibex and porcupine (i.e. for those species, cluster analysis showed that the various methods corroborated each other). For other species, however, the number of clusters of records from the various methods was low, which is attributable to a single method predominating in terms of recording success. This was the case for the hyaena and hyrax, which were predominantly recorded by skill-dependent methods (tracks and scats, respectively). The caracal was also predominantly recorded using a single, but non skill-dependent, method (faecal DNA). The hyaena's hind and front tracks differ in size and shape, and hyrax dung is usually found clustered near colonies and is markedly different from that of other herbivores in the region.

Our results show that methods vary in their ability to detect species of mammals. Some species would not have been recorded if the single method that detected them had not been used. The distribution of other species would have been underestimated (i.e. the hyaena, detected mainly by tracks; the hyrax, detected mainly from dung piles; and the caracal, detected from faecal DNA).

\section{Conclusions}

Our results indicated the best methods for detecting and recording distributions of individual mammal species in the study area, and demonstrated the advantage of using multiple methods to reduce the risk of false absences or partial detections. Our findings also highlight the potential of clustering for cross-checking the results of observations that are skill-dependent, which is particularly useful when employing a large workforce.

Our findings have broad applications for surveying terrestrial mammals. Single methods often fail to detect target species, and thus a multiple-method approach is necessary to identify the most appropriate methods for the target species, region and habitat. We have shown that a combination of methods can produce information at a faster rate and result in a more complete mammal survey than any single method.

\section{Acknowledgements}

Local guiding, logistic and institutional support were provided by Hadi al Hikmani, Andrew Spalton, Mansoor Hamed Al Jahdhami, Sheikh Mohammed Al Balushi and Khalifa al Jahwari. We are also grateful for the participation of rangers from the Ministry of Environment \& Climate Affairs. Corporate support came from Land Rover \& Swarovski Optik, and from The Ford Motor Company Conservation and Environmental Grants. We thank the volunteers who participated in the 2011 expedition to Oman, and Paul O'Dowd for his participation as expedition leader. The manuscript was enhanced by the critiques of two anonymous reviewers and Andrew Spalton, and a language review by Kimberly Ryan Mazzolli.

\section{References}

Al Hickmani, H., Zaabanoot, N. \& ZaAbanoot, A. (2015) Camera trapping of Arabian leopard in the Nejd region of Dhofar Mountains. Cat News, 62, 32.

Ausband, D.E., Rich, L.N., Glenn, E.M., Mitchell, M.S., Zager, P., Miller, D.A.W. et al. (2014) Monitoring gray wolf populations using multiple survey methods. The Journal of Wildife Management, 78, 335-346.

Balme, G.A., Hunter, L.T.B. \& Slotow, R. (2009) Evaluating methods for counting cryptic carnivores. The Journal of Wildlife Management, 73, 433-441.

Boulinier, T., Nichols, J.D., SAuer, J.R., Hines, J.E. \& Pollock, K.H. (1998) Estimating species richness: the importance of heterogeneity in species detectability. Ecology, 79, 1018-1028.

Brightsmith, D.J., Stronza, A. \& Holle, K. (2008) Ecotourism, conservation biology, and volunteer tourism: a mutually beneficial triumvirate. Biological Conservation, 141, 2832-2842.

Buesching, C.D., Newman, C. \& Macdonald, D.W. (2014) How dear are deer volunteers: the efficiency of monitoring deer using teams of volunteers to conduct pellet group counts. Oryx, 48, 593-601.

Burnham, K.P., Anderson, D.R. \& LaAke, J. (1980) Estimation of Density from Line Transect Sampling of Biological Populations. Wildlife Monographs 72. Wildlife Society, Louisville, USA.

Cohn, J.P. (2008) Citizen science: can volunteers do real research? BioScience, 58, 192-197. 
Davison, A., Birks, J.D.S., Brookes, R.C., Braithwaite, T.C. \& Messenger, J.E. (2002) On the origin of faeces: morphological versus molecular methods for surveying rare carnivores from their scats. Journal of Zoology, 257, 141-143.

Gompper, M.E., Kays, R.W., Ray, J.C., Lapoint, S.D., Bogan, D.A \& CRYAN, J.R. (2006) A comparison of noninvasive techniques to survey carnivore communities in northeastern North America. Wildlife Society Bulletin, 34, 1142-1151.

Guillera-Arroita, G., Lahoz-Monfort, J.J., MacKenzie, D.I., Wintle, B.A. \& McCarthy, M.A. (2014) Ignoring imperfect detection in biological surveys is dangerous: a response to 'Fitting and interpreting occupancy models'. PLoS ONE, 9(7), e99571.

Haag, T., Santos, A.S., De Angelo, C., Srbek-Araujo, A., Sana, D.A., Morato, R.G. et al. (2009) Development and testing of an optimized method for DNA-based identification of jaguar (Panthera onca) and puma (Puma concolor) faecal samples for use in ecological and genetic studies. Genetica, 136, 505-512.

Haag, T., Santos, A.S., Sana, D.A., Morato, R.G., Cullen, JR, L., Crawshaw, JR, P.G. et al. (2010) The effect of habitat fragmentation on the genetic structure of a top predator: loss of diversity and high differentiation among remnant populations of Atlantic Forest jaguars (Panthera onca). Molecular Ecology, 19, 4906-4921.

Hamfelt, A., Karlsson, M., Thierfelder, T. \& Valkovsky, V. (2011) Beyond K-means: clusters identification for GIS. In Information Fusion and Geographic Information Systems (eds V. Popovich, C. Claramunt, M. Schrenk \& K. Korolenko), pp. 93-105. Springer Berlin Heidelberg, New York, USA.

HARRISON, R.L. (2002) Evaluation of microscopic and macroscopic methods to identify felid hair. Wildlife Society Bulletin, 30, 412-419.

Howe, R.W., Wolf, A.T. \& Rinaldi, T. (1995) Monitoring birds in a regional landscape: lessons from the Nicolet National Forest Bird Survey. In Monitoring Bird Populations by Point Counts (eds C.J. Ralph, J.R. Sauer \& S. Droege), pp. 83-92. General Technical Report PSW-GTR-149. U.S. Department of Agriculture, Forest Service, Pacific Southwest Research Station, Albany, USA.

Hulik, T., Mazzolli, M. \& Hammer, M. (2015) True White Wilderness: Tracking Lynx, Wolf and Bear in the Carpathian Mountains of Slovakia. Biosphere Expeditions report. London, UK.

IUCN (2015) The IUCN Red List of Threatened Species v. 2015.2. Http:// www.iucnredlist.org [accessed 28 July 2015].

JACQUeZ, G.M. (2008) Spatial cluster analysis. In The Handbook of Geographic Information Science (eds J.P. Wilson \& S. Fotheringham), pp. 395-416. Blackwell Publishing, Malden, USA.

Janecka, J.E., Jackson, R., Zhang, Y., Li, D., Munkhtsog, B., Buckley-Beason, V. \& Murphy, W.J. (2008) Population monitoring of snow leopards using noninvasive genetics. Cat News, $48,7-10$.

Karanth, K.U. \& NiChols, J.D. (1998) Estimation of tiger densities in India using photographic captures and recaptures. Ecology, 79, 2852-2862.

Karanth, K.U., Nichols, J.D. \& Kumar, N.S. (2004) Photographic sampling of elusive mammals in tropical forests. In Sampling Rare or Elusive Species (ed. W.L. Thompson), pp. 229-247. Island Press, Washington, DC, USA.

Kelly, M.J., Betsch, J., Wultsch, C., Mesa, B. \& Mills, L.S. (2012) Noninvasive sampling for carnivores. In Carnivore Ecology and Conservation: A Handbook of Techniques (eds L. Boitani \& R.A. Powell), pp. 47-69. Oxford University Press, Oxford, UK.

Khorozyan, I., Stanton, D., Mohammed, M., Al-Ra'il, W. \& Pittet, M. (2014) Patterns of co-existence between humans and mammals in Yemen: some species thrive while others are nearly extinct. Biodiversity and Conservation, 23, 1995-2013.
Kindberg, J., Ericsson, G. \& Swenson, J.E. (2009) Monitoring rare or elusive large mammals using effort-corrected voluntary observers. Biological Conservation, 142, 159-165.

Lee, A., Mazzolli, M., Tatum-Hume, E., Kirby, C. \& Hammer, M. (2010) Icons of the Amazon: Jaguars, Pumas, Parrots and Peccaries in Peru. Biosphere Expeditions report. London, UK.

MacKenzie, D.I. \& Nichols, J.D. (2004) Occupancy as a surrogate for abundance estimation. Animal Biodiversity and Conservation, $27,461-467$.

MacKenzie, D.I., Nichols, J.D., Lachman, G.B., Droege, S., Royle, J.A. \& Langtimm, C.A. (2002) Estimating site occupancy rates when detection probabilities are less than one. Ecology, 83, 2248-2255.

Mallon, D. \& Budd, K. (2011) Regional Red List Status of Carnivores in the Arabian Peninsula. IUCN, Gland, Switzerland, and Cambridge, UK. Https://portals.iucn.org/library/efiles/edocs/ RL-53-001.pdf [accessed 28 July 2015].

Mazzolli, M. (2009) Arabian leopard, Panthera pardus nimr, status and habitat assessment in northwest Dhofar, Oman (Mammalia: Felidae). Zoology in the Middle East, 47, 3-12.

Mazzolli, M. \& Hammer, L.A. (2013) Sampling and Analysis of Data for Large Terrestrial Mammals During Short-Term Volunteer Expeditions. Biosphere Expeditions, UK.

Mazzolli, M., Oliveira, V. \& Hammer, M. (2013) Studying Jaguars, Pumas and their Prey in Brazil's Atlantic Rainforest: The Jaguar Corridor. Expedition report. Biosphere Expeditions, UK.

Mondol, S., Karanth, K.U., Kumar, N.S., Gopalaswamy, A.M., Andheria, A. \& Ramakrishnan, U. (2009) Evaluation of non-invasive genetic sampling methods for estimating tiger population size. Biological Conservation, 142, 2350-2360.

Murray, A.T., Grubesic, T.H., Rey, S.J. \& Anselin, L. (2012) Spatial data uncertainty and cluster detection. Proceedings of the 2012 GIScience Meeting. Columbus, USA.

Newman, C., Buesching, C.D. \& Macdonald, D.W. (2003) Validating mammal monitoring methods and assessing the performance of volunteers in wildlife conservation- "Sed quis custodiet ipsos custodies?" Biological Conservation, 113, 189-197.

Nichols, J.D., Bailey, L.L., O'Connell, JR, A.F., Talancy, N.W., Campbell Grant, E.H., Gilbert, A.T. et al. (2008) Multi-scale occupancy estimation and modelling using multiple detection methods. Journal of Applied Ecology, 45, 1321-1329.

Nomani, S.Z., Carthy, R.R. \& Oli, M.K. (2008) Comparison of methods for estimating abundance of gopher tortoises. Applied Herpetology, 5, 13-31.

Otis, D.L., Burnham, K.P., White, G.C. \& Anderson, D.R. (1978) Statistical Inference from Capture Data on Closed Animal Populations. Wildlife Monographs 62. Wildlife Society, Louisville, USA.

Otтo, C.R.V. \& Roloff, G.J. (2011) Using multiple methods to assess detection probabilities of forest-floor wildlife. The Journal of Wildlife Management, 75, 423-431.

Perez, I., Geffen, E. \& Mokady, O. (2006) Critically Endangered Arabian leopards Panthera pardus nimr in Israel: estimating population parameters using molecular scatology. Oryx, 40, 295-301.

SaUer, J.R., Fallon, J.E. \& Johnson, R. (2003) Use of North American Breeding Bird Survey data to estimate population change for bird conservation regions. Journal of Wildlife Management, 67, $372-389$.

Schmeller, D.S., Henry, P-Y., Julliard, R., Gruber, B., Clobert, J., Dziock, F. et al. (2009) Advantages of volunteer-based biodiversity monitoring in Europe. Conservation Biology, 23, 307-316.

Shannon, G., Lewis, J.S. \& Gerber, B.D. (2014) Recommended survey designs for occupancy modelling using motion-activated cameras: insights from empirical wildlife data. PeerJ, 2, e 532. 
Silveira, L., JÁсомo, A.T.A. \& Diniz-Filho, J.A.F. (2003) Camera trap, line transect census and track surveys: a comparative evaluation. Biological Conservation, 114, 351-355.

Spalton, J.A. (2000) The Arabian leopard in Oman. Cat News, 32, 6-7.

Spalton, J.A. \& Al Hikmani, H. (2014) The Arabian Leopards of Oman. Stacey International, London, UK.

Spalton, J.A., Al Hikmani, H.M., Willis, D. \& SAid, A.S.B. (2006) Critically Endangered Arabian leopards Panthera pardus nimr persist in the Jabal Samhan Nature Reserve, Oman. Oryx, 40, 287-294.

Vanstreels, R.E.T., Ramalho, F.P. \& Adania, C.H. (2010) Microestrutura de pêlos-guarda de felídeos brasileiros: considerações para a identificação de espécies. Biota Neotropical, 10, 333-337.

Vine, S.J., Crowther, M.S., Lapidge, S.J., Dickman, C.R., Mooney, N., Piggott, M.P. \& English, A.W. (2009) Comparison of methods to detect rare and cryptic species: a case study using the red fox (Vulpes vulpes). Wildlife Research, 36, 436-446.

Zielinski, W.J. \& Kucera, T.E. (1995) American Marten, Fisher, Lynx, and Wolverine: Survey Methods for their Detection. General
Technical Report PSW-GTR-157. U.S. Department of Agriculture, Forest Service, Pacific Southwest Research Station, Albany, USA.

\section{Biographical sketches}

Marcelo Mazzolli has over 2 decades of experience in wildlife research, mainly on the ecology of felids in the context of broader environmental processes at landscape and regional scales. TA IANA H A A G's research focuses on the characterization and genetic diversity of large felids in Brazil. BEATRIZ GARCIA LIPPERT has broad interests within the fields of environment and education, focusing on the genetic characterization of Brazilian mammals. EDUARDO EIZIRIK has studied the genetic polymorphism of felids for 20 years, while also exploring their phylogenetic and evolutionary relationships. Matтнias HAMMER is the founder of Biosphere Expeditions, and has led volunteer-based environmental research and conservation expeditions to various regions. KHALID AL HIKMANI works as a researcher, and guides wildlife research expeditions in Oman. 